\title{
Fermentation Enzymes in Strictly Aerobic Bacteria: Comparative Studies on Strains of the Genus Alcaligenes and on Nocardia opaca and Xanthobacter autotrophicus
}

\author{
By ALEXANDER STEINBÜCHEL, MICHAEL KUHN, \\ MATTHIAS NIEDRIG AND HANS G. SCHLEGEL* \\ Institut für Mikrobiologie der Universität Göttingen, Grisebachstraße 8, D-3400 Göttingen, \\ Federal Republic of Germany
}

(Received 7 February 1983; revised 29 April 1983)

\begin{abstract}
Nocardia opaca, Xanthobacter autotrophicus and 18 representative strains of the genus Alcaligenes were examined for the presence of NAD-dependent dehydrogenases for lactate, ethanol or 2,3butanediol after the cells had been transiently cultivated under conditions of oxygen deficiency. Formation of these enzymes was derepressed in all strains except Nocardia opaca and Alcaligenes latus. The protein patterns of Alcaligenes hydrogenophilus and Alcaligenes eutrophus type strain and strains N9A, H16, B19, H1 and H20 obtained by PAGE were similar. The purified lactate dehydrogenases from these strains were strongly inhibited by 1 to $5 \mu \mathrm{M}$-oxaloacetate, had a broad substrate specificity and a high affinity for Matrex ${ }^{\mathrm{TM}}$ Gel Green A. Alcaligenes faecalis shared the properties of the lactate dehydrogenase but differed greatly with respect to its protein pattern. In A. eutrophus strain A7 a high activity of lactate dehydrogenase was detected, but the enzyme was not sensitive to oxaloacetate.

Alcohol dehydrogenase and 2,3-butanediol dehydrogenase were even more widely distributed than lactate dehydrogenase among the strains studied. In many cases the electrophoretic mobilities of both alcohol dehydrogenases were identical. The study results in the following taxonomical conclusions. Alcaligenes eutrophus type strain and strains N9A, H16, B19, H1 and $\mathrm{H} 20$ are almost identical with respect to protein and enzyme patterns as well as the presence of a derepressible $\mathrm{L}(+)$-lactate dehydrogenase sensitive to oxaloacetate. The strains $\mathrm{CH} 34,707, \mathrm{~A} 7$ and JMP134 differ greatly from this core group and from each other and have to be considered as aberrant strains of $A$. eutrophus.
\end{abstract}

\section{INTRODUCTION}

The presence of NAD-linked dehydrogenases for lactate, 2,3-butanediol and ethanol in Alcaligenes eutrophus strain N9A had been demonstrated previously (Schlegel \& Vollbrecht, 1980). These fermentation enzymes were not expected to be present in strictly respiratory bacteria and are only formed when $A$. eutrophus is cultivated under conditions of restricted oxygen supply (Schlegel \& Steinbüchel, 1981). Recently, L(+)-lactate dehydrogenase (Steinbüchel \& Schlegel, 1983a,b) and alcohol dehydrogenase (unpublished results) from $A$. eutrophus strain N9A have been purified to homogeneity and characterized. This organism served as a model for our studies on enzyme derepression in strictly respiratory bacteria under conditions of oxygen deficiency.

The lactate dehydrogenase from $A$. eutrophus is characterized by three major distinguishing properties. It can easily be purified several hundred-fold from crude extracts by chromatography on Matrex ${ }^{\mathrm{TM}}$ Gel Green A due to the remarkably high affinity of this enzyme for the carrierlinked triazine dye (Steinbüchel \& Schlegel, 1983a,c). The purified lactate dehydrogenase exhibits a broad substrate spectrum allowing the reduction of 2-oxoacids other than pyruvate at 
a similar rate. Furthermore, enzyme activity is strongly inhibited by low concentrations of oxaloacetate (Steinbüchel \& Schlegel, 1983b). The alcohol dehydrogenase from this bacterium exhibits 2,3-butanediol dehydrogenase activity, and both activities may be due to the same protein. Both activities were inhibited by 2-mercaptoethanol. The present study included Xanthobacter autotrophicus strain 7C, Nocardia opaca strain $1 \mathrm{~b}$ and 18 different strains and species of Alcaligenes; the aim was to detect activities of lactate dehydrogenase, ethanol dehydrogenase and butanediol dehydrogenase after the incubation of these bacteria under conditions which resulted in derepression of these enzymes in strain N9A. Furthermore, the distribution of the unusual lactate and ethanol dehydrogenase among bacteria other than $A$. eutrophus was of interest. A further hint about taxonomical relationships was derived by comparing the electrophoresis patterns of cytoplasmic cell proteins.

\section{METHODS}

Bacterial strains. Sources and references of strains of the genus Alcaligenes, $N$. opaca and $X$. autotrophicus used in this study are listed in Table 1. Strain N9AF06 and strain TF97 are plasmid-free derivatives of strain N9A and the type strain, respectively, of $A$. eutrophus.

Growth of bacteria. Bacteria were grown heterotrophically in 41 gluconate-mineral medium (Steinbüchel \& Schlegel, 1983a) in glass fermenters (Schütt, Göttingen, F.R.G.). The cultures were aerated with $500 \mathrm{ml}$ air $\mathrm{min}^{-1}$ and agitated at 630 r.p.m. at $30^{\circ} \mathrm{C}$. After exponential growth with unrestricted oxygen supply to a density of approximately $2 \mathrm{~g} \mathrm{dry} \mathrm{wt}^{-1}, 1.5 \%(\mathrm{w} / \mathrm{v})$ sodium gluconate was added, and the aeration rate was decreased to 30 to $50 \mathrm{ml}$ air $\mathrm{min}^{-1}$ (Schlegel \& Steinbüchel, 1981). The $\mathrm{pH}$ was continuously adjusted by a pH-stat to 7.0. After 15 to $20 \mathrm{~h}$ of cultivation under these conditions of restricted oxygen supply, the bacteria were harvested, washed with $100 \mathrm{mM}$-potassium phosphate buffer, $\mathrm{pH} 7 \cdot 0$, and frozen at $-20^{\circ} \mathrm{C}$.

Some strains required a modified treatment. Alcaligenes faecalis was cultivated at a temperature of $37^{\circ} \mathrm{C}$. Alcaligenes latus was grown on $1.5 \%(\mathrm{w} / \mathrm{v})$ fructose at $35^{\circ} \mathrm{C}$. The gluconate medium for the cultivation of Alcaligenes ruhlandii was supplied with $1.5 \%(\mathrm{w} / \mathrm{v})$ nutrient broth; the corresponding amount was also added when the aeration rate was decreased. The growth substrate for Alcaligenes denitrificans was glucose $(1.5 \%, \mathrm{w} / \mathrm{v})$. Nocardia opaca was grown in 1 litre Erlenmeyer flasks containing $300 \mathrm{ml}$ gluconate-mineral medium. To induce oxygen deficiency, three exponentially grown cultures were combined in one 1 litre flask and then incubated without additional aeration. Samples for enzyme determination were taken throughout the incubation period.

Growth measurements. Optical densities were measured in $1 \mathrm{~cm}$ cuvettes at a wavelength of 436 or $546 \mathrm{~nm}$ in a Zeiss PL4 filter photometer. An absorbance of 10 corresponded to a bacterial density of about $2 \mathrm{mg}$ dry wt ml-1.

Preparation of protein extracts. Approximately $1 \mathrm{~g}$ wet wt of cells was resuspended in $4 \mathrm{ml} 100 \mathrm{mM}$-potassium phosphate buffer, $\mathrm{pH} 7 \cdot 0$, and broken by ultrasonication $(5 \mathrm{~min})$ using an MSE (150-W) ultrasonic disintegrator with a probe of $9.5 \mathrm{~mm}$ diameter. The sonicate was then centrifuged for $1 \mathrm{~h}$ at $100000 \mathrm{~g}$ in an Omicron ultracentrifuge (Heraeus-Christ, Osterode, F.R.G.) to remove cell debris and particulate matter.

Determination of enzyme activities. The activities of lactate dehydrogenase (EC 1.1.1.27), alcohol dehydrogenase (EC 1.1.1.1) and 2,3-butanediol dehydrogenase (EC 1.1.1.4) were determined by measuring the absorbance changes at $366 \mathrm{~nm}$ accompanying $\mathrm{NAD}(\mathrm{H})$ reduction (oxidation) at $30^{\circ} \mathrm{C}$ using a Zeiss PL4 filter photometer. Lactate dehyrogenase was assayed as described (Steinbüchel \& Schlegel, 1983a). Assays of alcohol dehydrogenase (ethanol oxidation) and 2,3-butanediol dehydrogenase (butanediol oxidation) were performed in semicarbazide/ pyrophosphate buffer, $\mathrm{pH} 8 \cdot 9$, and glycine/ $\mathrm{NaOH}$ buffer, $\mathrm{pH} 9 \cdot 2$, containing $37 \mathrm{~mm}$-2,3-butanediol as described by Bergmeyer (1974) and Höhn-Bentz \& Radler (1978), respectively. In samples with no or low alcohol dehydrogenase and 2,3-butanediol dehydrogenase activities the reverse reactions of these enzymes were measured in $3.0 \mathrm{ml} 100 \mathrm{~mm}$-potassium phosphate buffer, $\mathrm{pH} 7.0$, containing $0.24 \mathrm{mM}-\mathrm{NADH}$ and $2.0 \mathrm{~mm}$-acetaldehyde or $2.0 \mathrm{~mm}$-acetoin, respectively. One unit (U) of enzyme activity transformed $1 \mu \mathrm{mol}$ substrate per minute.

Electrophoretic methods. PAGE was performed in a flat gel apparatus for vertical slab electrophoreses (Pantophor, Müller, Hann. Münden, F.R.G.) with $3 \mathrm{~mm}$ gels $(7.5 \%$, w/v, acrylamide) in Tris/borate buffer (30 mM-Tris, $71 \mathrm{~mm}$-boric acid) at $\mathrm{pH} 8 \cdot 9$. Crude extracts were diluted with $100 \mathrm{mM}$-potassium phosphate buffer, $\mathrm{pH} 7 \cdot 0$, to give a protein concentration of about $10 \mathrm{mg} \mathrm{ml}^{-1} ; 10 \%(\mathrm{w} / \mathrm{v})$ sucrose and $0.005 \%$ amido black were added and $25 \mu \mathrm{l}$ of this solution was applied to the gel. Electrophoresis was carried out at $400 \mathrm{~V}$ and $50 \mathrm{~mA}$ for about $1.5 \mathrm{~h}$ until the band of the tracking dye (amido black) had migrated $10.0 \mathrm{~cm}$. Protein was stained with Coomassie brilliant blue (Weber \& Osborn, 1969). For enzyme activity staining, gel strips were incubated at $30^{\circ} \mathrm{C}$ in the dark in $100 \mathrm{~mm}$-potassium phosphate buffer, $\mathrm{pH} \mathrm{7.6}$, in the presence of $\left(\mathrm{mg} \mathrm{ml}^{-1}\right)$ : NAD, $0 \cdot 7$; 4nitrobluetetrazolium chloride, 0.4; phenazine methosulphate, 0.025 ; and $\mathrm{L}(+)$-lactate, 13 (for lactate dehydrogenase), or ethanol, 25 (for alcohol dehydrogenase), or 2,3-butanediol, 25 (for butanediol dehydrogenase), until bands of activity became visible (usually after 2 to $6 \mathrm{~h}$ ). Relevant controls ensured that bands were specific 
for the respective enzyme activity. The stain was discarded, and the gels were rinsed with water and then stored in $7 \%(\mathrm{v} / \mathrm{v})$ acetic acid at $4{ }^{\circ} \mathrm{C}$.

Preparation of Cibacron Blue F3G-A-Sepharose. Cibacron Blue F3G-A was coupled to Sepharose 6B-CL following the procedure of Atkinson et al. (1981).

Purification of lactate dehydrogenase from crude extracts. All steps were carried out at 0 to $4{ }^{\circ} \mathrm{C}$ in $100 \mathrm{~mm}-$ potassium phosphate buffer, pH 7.0, containing $4 \mathrm{~mm}-2$-mercaptoethanol. Cells $(6 \mathrm{~g}$ wet wt) were resuspended in $20 \mathrm{ml}$ buffer and broken by ultrasonication (twice, $4 \mathrm{~min}$ ) using an MSE (150-W) ultrasonic disintegrator with a probe of $19 \mathrm{~mm}$ diameter. The sonicate was centrifuged at $140000 \mathrm{~g}$ in a Beckmann L5-50B ultracentrifuge in a type 35 rotor $(6 \times 90 \mathrm{ml})$. To the resulting supernatant, which was referred to as crude extract, a solution containing $2.5 \%(\mathrm{w} / \mathrm{v})$ cetyltrimethylammonium bromide (CTAB) was added dropwise to give a final concentration of $2.7 \mathrm{mg} \mathrm{ml}^{-1}$. The precipitate was removed by centrifugation for $20 \mathrm{~min}$ at $40000 \mathrm{~g}$. The supernatant (18 to $20 \mathrm{ml})$ was applied to a column $\left(1.5 \times 2.4 \mathrm{~cm}, 4 \mathrm{ml}\right.$ bed volume) of Matrex ${ }^{\mathrm{TM}} \mathrm{Gel} \mathrm{Green} \mathrm{A}$ (Amicon Corp., U.S.A.). The column was washed with buffer which contained $\mathrm{KCl}$ in concentrations increasing stepwise. When lactate dehydrogenase activity began to appear in the eluate, $0.5 \mathrm{~mm}$-NADH was added to the final elution buffer (containing $500 \mathrm{~mm}$-potassium chloride in most cases). Fractions with high enzyme activitiy were combined, and salt and NADH were removed by using a diaflow chamber (Amicon Corp., U.S.A.) containing a PM10 filter. This Green A eluate was layered on top of a Cibacron Blue F3G-A-Sepharose column $(1.5 \times 2.4 \mathrm{~cm}, 4 \mathrm{ml}$ bed volume $)$. The column was washed successively with approximately 2 bed volumes buffer, 4 bed volumes buffer containing $100 \mathrm{~mm}-\mathrm{KCl}$ and finally with buffer containing $500 \mathrm{~mm}-\mathrm{KCl}$. Lactate dehydrogenase was eluted from the column at the final step. Fractions with high enzyme activity were combined and referred to as Blue $A$ eluate.

Protein determination. Soluble protein was routinely determined by the method of Bradford (1976).

Determination of poly-3-hydroxybutanoate. Poly-3-hydroxybutanoate (PHB) was determined by the infrared spectrometric method according to Jüttner et al. (1975).

Chemicals. Sepharose 6B-CL was obtained from Pharmacia. Matrex ${ }^{\mathrm{TM}}$ Gel Green A was purchased from Amicon (Lexington, U.S.A.) and phenazine methosulphate from Sigma. Acrylamide, $N, N^{\prime}$-methylenebisacrylamide, $N, N, N^{\prime}, N^{\prime}$-tetramethylethylenediamine, Cibacron Blue F3G-A and 4-nitrobluetetrazolium chloride were from Serva (Heidelberg, F.R.G.).

\section{RESULTS}

\section{Wide distribution of fermentation enzymes}

All enzyme data refer to cells which, after growth, had been kept under conditions of restricted oxygen supply for about 15 to $20 \mathrm{~h}$. The most remarkable result of this study pertains to the recognition of the wide distribution of the ability to form fermentation enzymes among strictly respiratory bacteria. Almost all strains studied proved to be able to synthesize NADdependent dehydrogenases for lactate, ethanol or 2,3-butanediol, if they were transiently cultivated under conditions of restricted oxygen supply. Nocardia opaca strain $1 \mathrm{~b}$ and $A$. latus were the only strains which lacked these activities under the conditions described (Table 1, Fig. 1).

The formation of fermentation enzymes was accompanied by the synthesis of PHB in almost all those bacteria which are known to be able to form this storage material. Alcaligenes hydrogenophilus, for instance, accumulated PHB up to $45 \%$ of the bacterial cell mass. The role of PHB as an internal fermentation product (Senior \& Dawes, 1973; Senior et al., 1972; Schlegel \& Steinbüchel, 1981) was herewith confirmed.

\section{Formation and properties of NAD-dependent lactate dehydrogenase}

Significant activities of NAD-dependent lactate dehydrogenases were detected in A. faecalis, $A$. hydrogenophilus, $X$. autotrophicus and $A$. eutrophus strains H16, N9A and derivatives, B19, TF97, H1, H20 and A7 following growth with restricted aeration. The presence of enzyme activity was demonstrated both by measuring the rate of pyruvate reduction and by activity staining after PAGE. The lactate dehydrogenase from each strain was purified several hundredfold to approximately $95 \%$ homogeneity.

Lactate dehydrogenase from $X$. autotrophicus was highly sensitive to CTAB and was not further investigated due to the low recovery of activity after precipitation by CTAB. The lactate dehydrogenases of the other strains showed remarkably high affinities for Matrex ${ }^{\mathrm{TM}}$ Gel Green A; 
Table 1. Bacterial strains used and major properties of intact cells, enzyme activities, electrophoretic mobilities and PHB synthesis

Enzyme activities were determined as described in Methods; the values represent the highest specific activities reached within $20 \mathrm{~h}$ after exposing the cells to restricted oxygen supply. The values in parentheses show activities for the reverse reaction, i.e. alcohol formation. The position of activity

\begin{tabular}{|c|c|c|c|c|c|}
\hline \multirow[b]{2}{*}{ Species and strain } & \multirow[b]{2}{*}{ Reference or source* } & \multirow[b]{2}{*}{ Substrate } & \multicolumn{3}{|c|}{$\begin{array}{c}\text { Specific activity }{ }_{\left[\mathrm{mU}(\mathrm{mg} \text { protein })^{-1}\right]}\end{array}$} \\
\hline & & & LDH & $\mathrm{ADH}$ & $\mathrm{BuDH}$ \\
\hline A. eutrophus Hi6 & $\begin{array}{l}\text { ATCC 17699, DSM } 428 \\
\text { (Wilde, 1962) }\end{array}$ & Gluconate & 353 & 15 & 235 \\
\hline A. eutrophus N9A & $\begin{array}{l}\text { DSM } 518 \\
\text { (Schuster, 1967) }\end{array}$ & Gluconate & 489 & 26 & 285 \\
\hline A. eutrophus $\mathrm{N} 9 \mathrm{~A}-\mathrm{PHB}^{-} 02-\mathrm{HB}^{-1}$ & DSM 1347 & Gluconate & 335 & 21 & 246 \\
\hline A. eutrophus N9AF06 & $\begin{array}{l}\text { Plasmid-free strain from } \\
\text { DSM } 518 \text { (B. Friedrich, } \\
\text { pers. comm.) }\end{array}$ & Gluconate & 020 & 34 & 395 \\
\hline A. eutrophus B19 & $\begin{array}{l}\text { DSM } 515 \\
\text { (Schuster, 1967) }\end{array}$ & Gluconate & 435 & 12 & 327 \\
\hline A. eutrophus $\mathrm{H} 1$ & ATCC 17698 & Gluconate & 401 & $\begin{array}{c}15 \\
(1433)\end{array}$ & 1391 \\
\hline A. eutrophus $\mathrm{H} 20$ & $\begin{array}{l}\text { Institut für Mikrobiologie, } \\
\text { Göttingen, F.R.G. }\end{array}$ & Gluconate & 296 & $\begin{array}{c}18 \\
(525)\end{array}$ & 795 \\
\hline A. eutrophus TF97 & $\begin{array}{l}\text { Plasmid-free strain from } \\
\text { DSM } 531 \text { (Friedrich } \\
\text { et al., 1981a) }\end{array}$ & Gluconate & 082 & 28 & 512 \\
\hline A. eutrophus 707 & ATCC 17707 & Gluconate & 10 & 60 & 417 \\
\hline A. eutrophus $\mathrm{CH} 34$ & (Mergeay et al., 1978) & Gluconate & 15 & $\begin{array}{c}11 \\
(1034)\end{array}$ & 855 \\
\hline A. eutrophus JMP134 & (Pemperton et al., 1979) & Gluconate & 10 & 87 & 26 \\
\hline A. eutrophus A7 & (Schwien \& Schmidt, 1982) & Gluconate & 456 & 115 & $\begin{array}{c}7 \\
(1357)\end{array}$ \\
\hline A. denitrificans & CIP 21.75 & Glucose & 10 & 75 & 31 \\
\hline A. faecalis & CIP 62.31 & Gluconate & 548 & $\begin{array}{r}0 \\
(50)\end{array}$ & 73 \\
\hline A. hydrogenophilus 1978 & (Ohi et al., 1979) & Gluconate & 68 & 21 & 813 \\
\hline A. latus & $\begin{array}{l}\text { DSM } 1123 \\
\text { (Palleroni \& Palleroni, 1978) }\end{array}$ & Fructose & 20 & $\begin{array}{c}0 \\
(0)\end{array}$ & $\begin{array}{c}0 \\
(0)\end{array}$ \\
\hline A. paradoxus 1360 & ATCC 17722 & Gluconate & 0 & 57 & 0 \\
\hline A. ruhlandii & ATCC 15749, DSM 653 & $\begin{array}{c}\text { Gluconate }+ \\
\text { nutrient broth }\end{array}$ & 20 & 123 & 39 \\
\hline N. opaca $1 \mathrm{~b}$ & DSM 427 & Gluconate & 0 & $\begin{array}{c}0 \\
(0)\end{array}$ & $\begin{array}{c}0 \\
(0)\end{array}$ \\
\hline X. autotrophicus $7 \mathrm{C}$ & DSM 432 & Gluconate & 41 & $\begin{array}{c}0 \\
(326)\end{array}$ & 440 \\
\hline
\end{tabular}

ND, not determined.

* ATCC, American Type Culture Collection; CIP, Collection de l'Institut Pasteur; DSM, Deutsche Sammlung von Mikroorganismen.

† ADH, alcohol dehydrogenase; BuDH, 2,3-butanediol dehydrogenase; LDH, lactate dehydrogenase.

high activities were adsorbed by relatively small amounts of the affinity matrix, as has been described previously for the enzyme from $A$. eutrophus strain N9A-PHB-02-HB-1 (Steinbüchel \& Schlegel, $1983 a, c)$. Enzymes were eluted with $500 \mathrm{~mm}$-potassium chloride and $0.5 \mathrm{~mm}$ NADH in the final step. Only lactate dehydrogenase from $A$. eutrophus A7 was eluted by $150 \mathrm{~mm}$-potassium chloride. The enzyme from $A$. faecalis did not elute as a sharp peak: activity was detected in every fraction tested including those to which no potassium chloride had been 
Table 1.--continued.

bands in polyacrylamide gels is characterized by their relative mobility referred to amido black. For $\mathrm{ADH}$ and $\mathrm{BuDH}$ the pairs of values represent in each case two bands of activity. The values in parentheses represent relative mobilities of minor activity bands.

\begin{tabular}{|c|c|c|c|c|c|}
\hline \multicolumn{3}{|c|}{ Relative mobilities of activity bands in PAGE $\dagger$} & \multirow{2}{*}{$\begin{array}{c}\text { PHB synthesis } \\
\text { under restricted } \\
\qquad \mathrm{O}_{2 \ddagger}^{\ddagger}\end{array}$} & \multirow{2}{*}{$\begin{array}{c}\text { Inhibition of } \\
\text { BuDH by } \\
\text { 2-mercaptoethanol§ }\end{array}$} & \multirow{2}{*}{$\begin{array}{l}\text { Purified } \\
\text { LDH }\end{array}$} \\
\hline LDH & $\mathrm{ADH}$ & BuDH & & & \\
\hline 0.52 & $0.44,0.46$ & $0 \cdot 44,0 \cdot 46$ & ++ & $100 \cdot 0$ & + \\
\hline 0.52 & $0 \cdot 44,0 \cdot 46$ & $0.44,0.46$ & ++ & $100 \cdot 0$ & + \\
\hline 0.52 & $0.44,0.46$ & $0.44,0.46$ & ++ & $100 \cdot 0$ & - \\
\hline 0.52 & $0 \cdot 44,0 \cdot 46$ & $0 \cdot 44,0 \cdot 46$ & ++ & $95 \cdot 9$ & + \\
\hline $0 \cdot 52$ & $0 \cdot 44,0 \cdot 46$ & $0.44,0 \cdot 46$ & ++ & $100 \cdot 0$ & + \\
\hline 0.52 & $0.44,0.46$ & $0.44,0 \cdot 46$ & ++ & $98 \cdot 5$ & + \\
\hline $0 \cdot 52$ & $0 \cdot 44,0 \cdot 46$ & $0 \cdot 44,0 \cdot 46$ & ++ & $98 \cdot 4$ & + \\
\hline $0 \cdot 52$ & $0 \cdot 44,0 \cdot 46$ & $0 \cdot 44,0 \cdot 46$ & ++ & $96 \cdot 0$ & + \\
\hline- & $\begin{array}{c}0.36,0 \cdot 39 \\
(0 \cdot 53,0 \cdot 56)\end{array}$ & $0 \cdot 36,0 \cdot 39$ & ++ & $100 \cdot 0$ & - \\
\hline$(0 \cdot 61)$ & $0 \cdot 39,0 \cdot 40$ & $0 \cdot 39,0 \cdot 40$ & + & $96 \cdot 8$ & - \\
\hline- & $\begin{array}{c}0 \cdot 32,0 \cdot 33 \\
(0 \cdot 42,0 \cdot 44)\end{array}$ & $0 \cdot 32,0 \cdot 33$ & ++ & $100 \cdot 0$ & - \\
\hline 0.55 & $\begin{array}{c}0.31 \\
(0.42)\end{array}$ & $0 \cdot 31$ & + & $100 \cdot 0$ & + \\
\hline 0.56 & $0 \cdot 37,0 \cdot 39$ & $0 \cdot 26,0 \cdot 27$ & + & $100 \cdot 0$ & - \\
\hline 0.65 & 0.32 & & + & $100 \cdot 0$ & + \\
\hline$(0 \cdot 76)$ & $(0 \cdot 50)$ & 0.50 & & & \\
\hline 0.52 & $0 \cdot 44,0 \cdot 46$ & $0.44,0 \cdot 46$ & ++ & $100 \cdot 0$ & + \\
\hline- & 一 & - & ++ & ND & - \\
\hline - & $0 \cdot 56,0 \cdot 58$ & - & - & ND & - \\
\hline 0.56 & $\begin{array}{c}(0.26) \\
0.39\end{array}$ & 0.26 & - & $76 \cdot 0$ & - \\
\hline- & - & - & - & ND & - \\
\hline $\begin{array}{c}0.61 \\
(0.68)\end{array}$ & 0.24 & 0.24 & + & $63 \cdot 3$ & - \\
\hline
\end{tabular}

$\ddagger$ The symbols for synthesis of PHB refer to the proportion of polymer relative to bacterial cell mass after exposing cells to restricted oxygen supply for $15-20 \mathrm{~h}:++, 25-50 \% ;+$, up to $15 \% ;-$, PHB not detectable in significant amounts.

$\S$ Inhibition of 2,3-butanediol dehydrogenase by $1 \mathrm{~mm}$-2-mercaptoethanol was determined in the crude extract.

added. The broad elution profile may be due to the presence of two different enzymes as suggested by the results obtained by activity staining (Fig. 1d).

The eluates from the Green A column, which contained about $50 \%$ of the lactate dehydrogenase activity, were applied to Cibacron Blue F3G-A-Sepharose. Lactate dehydrogenase activities appeared in the eluate at $500 \mathrm{~mm}$-potassium chloride in all cases. Only lactate dehydrogenase from A. eutrophus $\mathrm{A} 7$ was eluted from the column by $100 \mathrm{~mm}$-potassium chloride. 
The similarity of the lactate dehydrogenases from A. eutrophus strains H16, N9A, B19, TF97, $\mathrm{H} 1$ and $\mathrm{H} 20$ or from $A$. hydrogenophilus was confirmed by the almost coincident migration behaviour during gel electrophoresis (Fig. $1 d$ ) and by the substrate specificity of the purified enzymes (Table 2). In addition, all enzymes showed the characteristic sensitivity to $1 \mu \mathrm{M}$ oxaloacetate as was described for the extensively characterized lactate dehydrogenase from $A$. eutrophus strain N9A-PHB-02-HB-1 (Steinbüchel \& Schlegel, 1983b). The properties of the lactate dehydrogenase from $A$. faecalis were similar, but $5 \mu \mathrm{M}$-oxaloacetate was required to reach inhibitory effects of more than $95 \%$, whereas $1 \mu \mathrm{M}$ caused almost no inhibition. The enzyme from $A$. eutrophus strain A7 differed with respect to its lower affinity for the triazine-dye affinity matrices, in reducing oxaloacetate at a significant rate and in its insensitivity to inhibition by oxaloacetate.

Only low lactate dehydrogenase activities $\left[20 \mathrm{mU}(\mathrm{mg} \text { protein })^{-1}\right]$ were detected in $A$. eutrophus strain $\mathrm{CH} 34$. No increase of enzyme activity was achieved when the incubation conditions were varied or when lower aeration rates (resulting in 0,6 and $36 \%$ of the maximum respiration rates) were employed. Furthermore, neither variation of the buffer systems nor desalting of crude extract on Sephadex G-25 resulted in increased enzyme activities. None of the
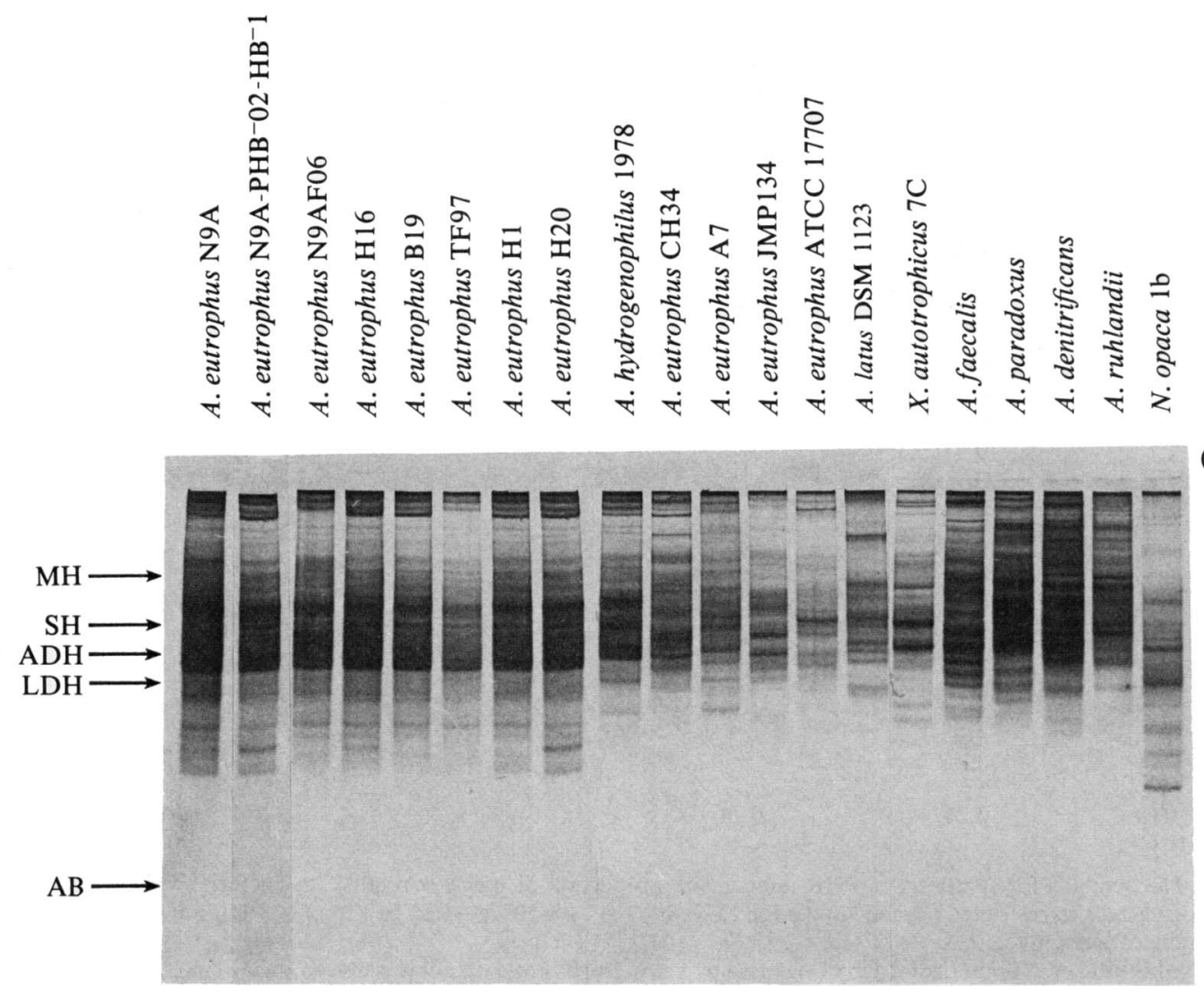

Fig. 1. (Continued on facing page). Electropherograms of cytoplasmic fractions of various strains of the genus Alcaligenes and of $N$. opaca and $X$. autotrophicus. About 200 to $250 \mu \mathrm{g}$ protein of the crude extracts of cells, which had been incubated for 15 to $20 \mathrm{~h}$ under conditions of restricted oxygen supply, were separated in Tris/borate buffer, $\mathrm{pH} \mathrm{8.9,} \mathrm{as} \mathrm{described} \mathrm{in} \mathrm{Methods.} \mathrm{After} \mathrm{electrophoresis,} \mathrm{the} \mathrm{gels}$ were stained either for protein $(a)$ or for activity of alcohol dehydrogenase $(b)$, 2,3-butanediol dehydrogenase $(c)$ and $\mathrm{L}(+)$-lactate dehydrogenase $(d)$. The arrows in $(a)$ indicate the position of membrane-bound hydrogenase $(\mathrm{MH})$, soluble hydrogenase $(\mathrm{SH})$, alcohol dehydrogenase (ADH) and lactate dehydrogenase (LDH) in the core strains of $A$. eutrophus, and of amido black (AB). In $(b),(c)$ and $(d)$ only those bands are shown which were specific for the respective enzyme activity. Bands which appeared independently from NAD or substrate are not shown. 
Fermentation enzymes in aerobic bacteria

落

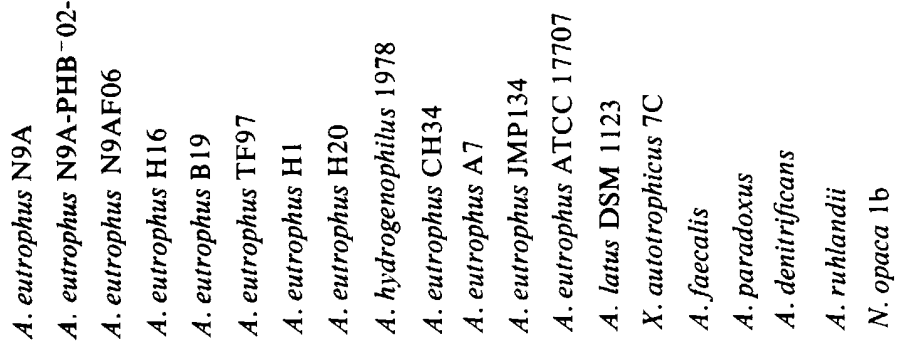

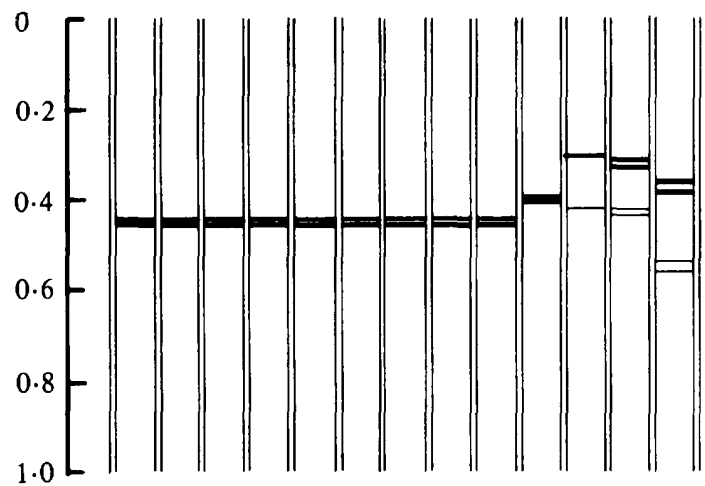

(b)

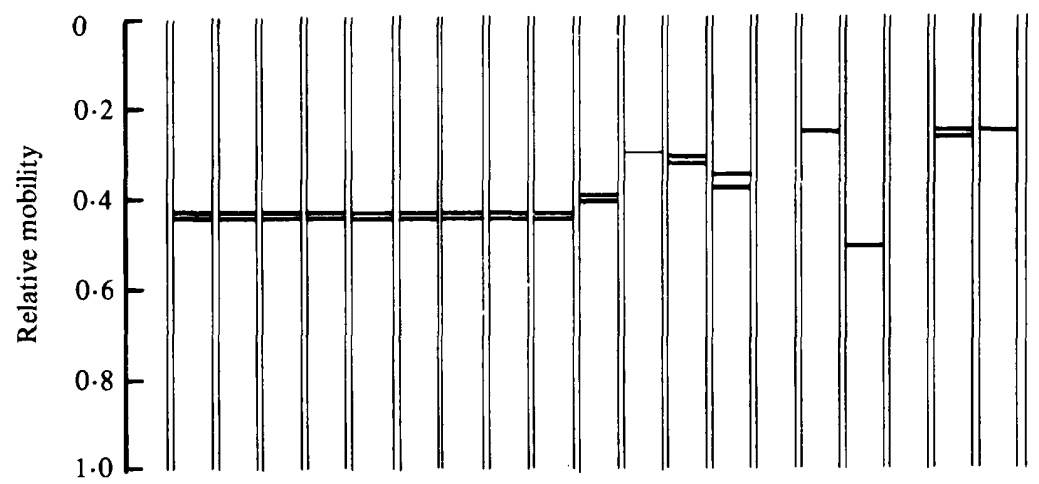

(c)

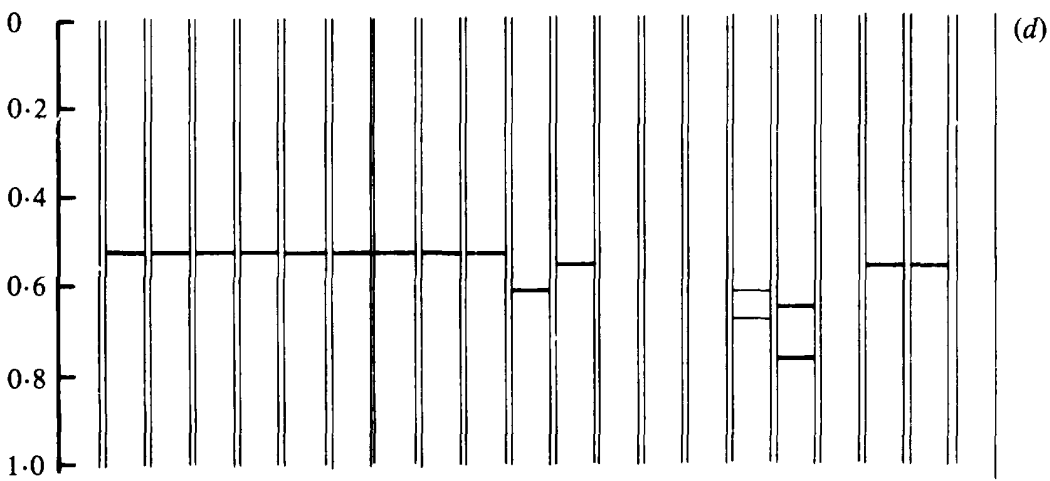

Fig. 1 (continued) 


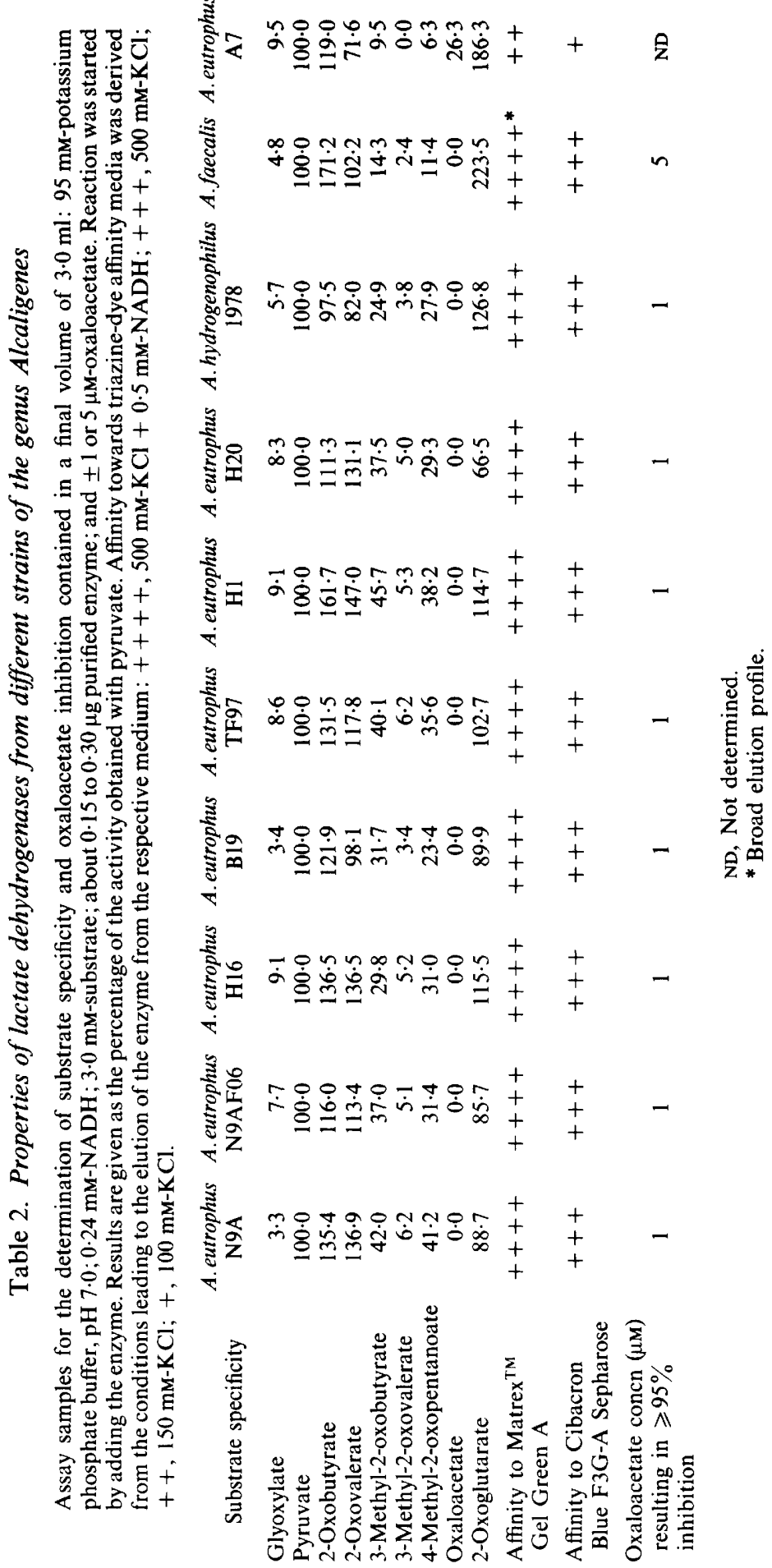


lactate dehydrogenase activities were activated by fructose 1,6-bisphosphate and $\mathrm{MgCl}_{2}$, which are known to stimulate the activities of other lactate dehydrogenases (Garvie, 1980).

\section{Formation of NAD-dependent alcohol and butanediol dehydrogenases}

Almost all of the strains studied contained high activities of alcohol and butanediol dehydrogenases which were separable by electrophoresis into two close but distinct bands in some strains. In those strains in which the properties of lactate dehydrogenase were similar, the electrophoretic mobilities of alcohol and butanediol dehydrogenase activities in polyacrylamide gels were coincident. The alcohol dehydrogenase from $A$. eutrophus N9A was purified to homogeneity (not shown here in detail). The purified enzyme had ethanol dehydrogenase activity as well as 2,3-butanediol dehydrogenase activity. The two activities could not be separated by a variety of methods. Extensive kinetic studies, which included the examination of inhibitory effects of various physiological metabolites and of 2-mercaptoethanol, strengthened the conclusion that in $A$. eutrophus both activities are due to the same enzyme protein. Furthermore, detailed studies of the purified alcohol dehydrogenase confirmed that the lower of the two close bands detected by electrophoresis represents a modified form of the native enzyme.

The electrophoretic mobilities of the alcohol dehydrogenase and butanediol dehydrogenase from $X$. autotrophicus, $A$. faecalis, $A$. paradoxus, $A$. denitrificans, $A$. ruhlandii and $A$. eutrophus strains CH34, A7, JMP134 and 707 were different from each other (Table 1 and Fig. 1). The discrete bands corresponding to each activity were close together in samples from a wide range of strains. The coincidence of the ethanol and butanediol dehydrogenase activity bands detectable in the electropherograms of some species indicates that both enzyme activities are probably due to the same enzyme protein. Distinct bands for alcohol dehydrogenase activity without butanediol dehydrogenase activity were found only in the gel tracks of $A$. eutrophus strains 707, JMP134 and A7. Alcaligenes paradoxus was the only strain in which alcohol dehydrogenase activity but no butanediol dehydrogenase activity was detected.

The butanediol dehydrogenases of most strains were almost completely inhibited by $1 \mathrm{~mm}-2$ mercaptoethanol, as was shown previously for the purified enzyme from $A$. eutrophus strain N9A. Only the butanediol dehydrogenases from $A$. ruhlandii and $X$. autotrophicus were inhibited to a minor extent (Table 1).

\section{Protein pattern}

The protein patterns obtained by electrophoretic separation of the cytoplasmic proteins of $A$. hydrogenophilus and $A$. eutrophus strains H16, N9A, B19, TF97, H1, and $\mathrm{H} 20$ were almost identical (Fig. 1 $a$ ). The protein pattern of all other strains deviated from this type to various extents. The highest degree of similarity between strains that differed from $A$. eutrophus existed between $\boldsymbol{A}$. denitrificans and $\boldsymbol{A}$. ruhlandii; this similarity was reflected not only by the protein pattern (Fig. 1a) but also by the pattern resulting from activity staining (Fig. $1 b-d$ ).

\section{Plasmid-free strains}

Identical activities of the fermentation enzymes were detected in the wild-type strain N9A of A. eutrophus and in its plasmid-free derivative N9AF06 as well as in the wild-type strain of the type strain of $A$. eutrophus and its plasmid-free derivative strain TF97. This indicates that these plasmids, which appear to be identical with the megaplasmid pHG1 isolated from $A$. eutrophus H16 (Friedrich et al., 1981 a), are not involved in the synthesis of fermentation enzymes.

However, the absence of the plasmid was reflected by the electrophoretic protein patterns. Compared to other strains the protein patterns of strains N9AF06 and TF97 lacked at least one major band (relative mobility of about $0 \cdot 08$, Fig. $1 a$ ).

Hydrogenase activities are derepressed in $A$. eutrophus under various growth conditions, those of restricted oxygen supply included (Friedrich et al., 1981 b), and can contribute 1 to $2 \%$ of the total cell protein (K. Schneider, personal communication). The protein band absent from N9AF06 and TF97 was not one of the hydrogenases; activity staining of the gels indicated that the relative mobility of soluble hydrogenase was 0.35 and of the membrane-bound enzyme, 0.24 . Furthermore, the electrophoretic mobilities of the soluble and membrane-bound hydrogenase 
purified from strain H16, which were kindly provided by Dr K. Schneider, were also not identical to the plasmid-encoded protein with a relative mobility of 0.08 , the major protein band.

\section{DISCUSSION}

Since the first report of the presence of NAD-dependent dehydrogenases for lactate, ethanol and butanediol in A. eutrophus N9A (Schlegel \& Vollbrecht, 1980), evidence has accumulated that many obligately aerobic bacteria, which rely only on a strictly respiratory metabolism, can form fermentation enzymes. This indicates that the corresponding genetic information is present. Typical fermentation products were detected in cultures of various $P$ seudomonas strains and Paracoccus denitrificans (Vollbrecht, 1980; Vollbrecht \& El Nawawy, 1980), and alcohol and 2,3-butanediol dehydrogenases were detected in strains of Paracoccus denitrificans (Nokhal, 1981) that had been cultivated under conditions of restricted oxygen supply. Recently, heterofermentative lactic acid fermentation was demonstrated in Thiobacillus neapolitanus (Beudeker et al., 1981). The present study expanded the group of strictly aerobic bacteria known to carry genetic information for fermentation enzymes. Among 20 strains investigated, only in $A$. latus and $N$. opaca were none of these enzyme activities detected. In view of the wide distribution of derepressible fermentation enzymes the question arises whether these 'silent genes' (Riley \& Anilionis, 1978) are redundant or may be profitable for this group of strictly aerobic bacteria.

A good correlation exists between the occurrence and properties of the three fermentation enzymes and the taxonomical assignment of the strains and species studied, with few exceptions. PAGE of the cytoplasmic proteins provided further characters for strain differentiation. The electrophoretic mobilities of the three enzymes as well as the banding patterns of the total soluble proteins reflected the differences and similarities detected by enzyme measurements and characterization. The suitability of protein electropherograms for differentiating various species of the genus Alcaligenes had been demonstrated before (Kersters \& De Ley, 1980).

Alcaligenes eutrophus strains H16, N9A and derivatives, B19, H1, H20 and TF97 were very similar to each other and indistinguishable with respect to both the electropherograms of cytoplasmic proteins and various properties of the three fermentation enzymes. Alcaligenes hydrogenophilus strain 1978 isolated in Japan (Ohi et al., 1979) was almost indistinguishable from most of the autotrophic A. eutrophus strains. As the similarity pertains to substrate specificity and even includes the presence of two hydrogenases (Schlegel, 1983), this strain should probably be considered to be a subspecies of $A$. eutrophus rather than a separate species.

Apart from the core of $A$. eutrophus and $A$. hydrogenophilus, A. faecalis CIP 62.31 was the only organism from which the lactate dehydrogenase was highly sensitive to oxaloacetate. However, the protein patterns after electrophoresis as well as the enzyme activity patterns differed significantly from the organisms mentioned above. On the basis of other data. $A$. faecalis CIP 62.31 is phenotypically and genotypically an aberrant strain, not belonging to $A$. faecalis, but belonging to the core group of $A$. eutrophus (K. Kersters, personal communication). By extending the investigations on the distribution of this remarkable lactate dehydrogenase the relationships between the species and strains of Alcaligenes, which is a taxonomically and physiologically heterogeneous group of bacteria, may be clarified.

This study has revealed that all other strains investigated differed widely from the core of $A$. eutrophus strains. Consequently, there are several reasons for removing $A$. eutrophus strain 707 , which is considered as a slightly aberrant $A$. eutrophus strain (K. Kersters, personal communication) and $A$. eutrophus strain JMP134, A7 and CH34 from the core of $A$. eutrophus. Alcaligenes ruhlandii and $A$. denitrificans showed some similarities to each other with respect to the protein pattern as well as to the enzyme pattern. This is in agreement with the results from Kersters et al. (1981).

We are indebted to Dr K. Kersters, Gent, for providing strains of Alcaligenes denitrificans, A. faecalis and $\boldsymbol{A}$. hydrogenophilus. Support of this work by the Deutsche Forschungsgemeinschaft is gratefully acknowledged. 


\section{REFERENCES}

Atxinson, T., Hammond, P. M., Hartwell, R. D., Hughes, P., Scawen, M. D., Sherwood, R. F., SMall, D. A. P., Bruton, C. J., Harvey, M. J. \& Lowe, C. R. (1981). Triazine-dye affinity chromatography. Biochemical Society Transactions 9, 290-293.

BERGMEYER, H. U. (1974). Methoden der Enzymatischen Analyse, vol. 1, 3rd edn. Weinheim: Verlag Chemie.

Beudeker, R. F., De Boer, W. \& Kuenen, J. G. (1981). Heterolactic fermentation of intracellular polyglucose by the obligate chemolithotroph Thiobacillus neapolitanus under anaerobic conditions. FEMS Microbiology Letters 12, 337-342.

BRADFORD, M. M. (1976). A rapid and sensitive method for the quantitation of microgram quantities of protein utilizing the principle of protein dye binding. Analytical Biochemistry 72, 248-254.

FrIEDRICH, B., HoGREFE, C. \& SCHLEGEL, H. G. $(1981 a)$. Naturally occurring genetic transfer of hydrogen-oxidizing ability between strains of Alcaligenes eutrophus. Journal of Bacteriology 147, 198-205.

FrIEDRICH, C. G., FRIEDRICH, B. \& BOWIEN, B. $(1981 b)$. Formation of enzymes of autotrophic metabolism during heterotrophic growth of Alcaligenes eutrophus. Journal of General Microbiology 122, 69-78.

GARVIE, E. L. (1980). Bacterial lactate dehydrogenases. Microbiological Reviews 44, 83-105.

HöHN-BENTZ, H. \& RADLER, F. (1978). Bacterial 2,3butanediol dehydrogenases. Archives of Microbiology 116, 197-203.

JÜTTNER, R. R., LAFFERTY, R. M. \& KNACKMUSS, H. J. (1975). A simple method for the determination of poly- $\beta$-hydroxybutyric acid in microbial biomass. European Journal of Applied Microbiology 1, 233-237.

Kersters, K. \& DE LeY, J. (1980). Classification and identification of bacteria by electrophoresis of their proteins. In Microbiological Classification and Identification, pp. 273-297. Edited by M. Goodfellow \& R. G. Board. London: Academic Press.

Kersters, K., Segers, P., Gayral, J. P. \& De Ley, J. (1981). The taxonomy of the genus Alcaligenes studied by auxanography and DNA :rRNA hybridizations. In Abstracts of the IV International Confer. ence on Culture Collections, p. 34, Brno.

Mergeay, M., Houba, C. \& GeriTs, J. (1978). Extrachromosomal inheritance controlling resistance to cadmium, cobalt and zinc ions: evidence from curing in a Pseudomonas. Archives internationales de physiologie et de biochimie 86, 440-441.

NoKhal, T.-H. A. A. (1981). Paracoccus denitrificans: Neuisolation und Untersuchungen zur Taxonomie und Stoffwechselphysiologie, pp. 117-151. Dissertation, Universität Göttingen, F.R.G.

OHI, K., TAKada, N., Komemushi, S., OKaZaki, M. \& MiURA, Y. (1979). A new species of hydrogenutilizing bacterium. Journal of General and Applied Microbiology 25, 53-58.

Palleroni, N. J. \& Palleroni, A. V. (1978). Alcaligenes latus, a new species of hydrogen-utilizing bacteria. International Journal of Systematic Bacteriology 28, 416-426.

Pemperton, J. M., Corney, B. \& Don, R. H. (1979). Evolution and spread of pesticide degrading ability among soil microoganisms. In Plasmids of Medical. Environmental and Commercial Importance, pp. 287-
299. Edited by K. N. Timmis \& A. Pühler. Amsterdam: Elsevier/North Holland Biomedical Press.

RiLeY, M. \& ANiLionis, A. (1978). Evolution of the bacterial genome. Annual Review of Microbiology 32, 519-560.

SCHLEGEL, H. G. (1983). Studies on the regulation and genetics of enzymes of Alcaligenes eutrophus. In Microbial Ecology and Metabolism. Edited by G. A. Codd \& W. D. P. Stewart. London, New York: Academic Press (in the press).

Schlegel, H. G. \& SteinbüChel, A. (1981). Die relative Respirationsrate (RRR), ein neuer Belüftungsparameter. In Fermentation, pp. 11-26. Edited by R. M. Lafferty. Wien, New York: Springer Verlag.

Schlegel, H. G. \& Vollbrecht, D. (1980). Formation of the dehydrogenases for lactate, ethanol and butanediol in the strictly aerobic bacterium Alcaligenes eutrophus. Journal of General Microbiology 117, 475-481.

SCHUSTER, E. (1967). Chemolithotrophes Wachstum von Hydrogenomonas HI6 im Chemostaten mit elektrolytischer Knallgaserzeugung. Dissertation, Universität Göttingen, F.R.G.

SCHWIEN, U. \& ScHMIDT, E. (1982). Improved degradation of monochlorophenols by a constructed strain. Applied and Environmental Microbiology 44, 33-39.

SENIOR, P. J. \& DAWES, E. A. (1973). The regulation of poly- $\beta$-hydroxybutyrate metabolism in Azotobacter beijerinckii. Biochemical Journal 134, 225-238.

SENIOR, P. J., BeECH, G. A., Ritchie, G. F. \& DAWES, E. A. (1972). The role of oxygen limitation in the formation of poly- $\beta$-hydroxybutyrate during batch and continuous culture of Azotobacter beijerinckii. Biochemical Journal 128, 1193-1201.

SteINBÜCHel, A. \& SCHLEGel, H. G. (1983a). NADlinked $\mathrm{L}(+)$-lactate dehydrogenase from the strict aerobe Alcaligenes eutrophus. 1. Purification and properties. European Journal of Biochemistry 130, 321-328.

SteINBüCHEL, A. \& SCHLEgel, H. G. (1983b). NADlinked $\mathrm{L}(+)$-lactate dehydrogenase from the strict aerobe Alcaligenes eutrophus. 2. Kinetic properties and inhibition by oxaloacetate. European Journal of Biochemistry 130, 329-334.

SteINBüchel, A. \& Schlegel, H. G. (1983c). The rapid purification of lactate dehydrogenase from Alcaligenes eutrophus in a two-step procedure. European Journal of Applied Microbiology and Biotechnology 17, 163-167.

VOLLBRECHT, D. (1980). Oxygen deficiency and excretion of metabolites by strictly aerobic bacteria. Biotechnology Letters 2, 49-54.

Vollbrecht, D. \& El Nawawy, M. A. (1980). Restricted oxygen supply and excretion of metabolites. I. Pseudomonas spec. and Paracoccus denitrifcans. European Journal of Applied Microbiology and Biotechnology 8, 135-143.

WEBER, K. \& OSBORN, M. (1969). The reliability of molecular weight determinations by dodecyl sulfate polyacrylamide gel electrophoresis. Journal of Biological Chemistry 244, 4406-4412.

WILDE, E. (1962). Untersuchungen über Wachstum und Speicherstoffsynthese von Hydrogenomonas. Archiv für Mikrobiologie 43, 109-137. 